\title{
The Level of Remuneration and Turnover Intention of Public Secondary School Teachers in Meru County: A Mixed Method Study
}

\author{
Peter Kalunge Ekabu (PhD) \\ University of Nairobi, Kenya
}

Doi:10.19044/esj.2019.v15n13p1 ～URL:http://dx.doi.org/10.19044/esj.2019.v15n13p1

\begin{abstract}
This paper focuses on establishing the relationship between the level of remuneration and turnover intentions of public secondary school teachers in Meru County. The study used a descriptive survey design with both quantitative and qualitative approaches in data collection and analysis. A total of 518 respondents were involved in the study which included secondary school teachers (503) and principals (15). The level of remuneration was examined to determine their relationships with the dependent variable, turnover intentions. Data obtained from questionnaires were analyzed quantitatively using SPSS version 21. Hypothesis was tested using Pearson product-moment correlation coefficient and Chi-square goodness of fit at $95 \%, \mathrm{p}<0.05$. The result from product-moment correlation indicated that the independent variable, level of remuneration $(r=-387, p<0.001)$, has a negative and an inverse relationship with the dependent variable, turnover intention. Chi-square analysis corroborated the results of Pearson correlation by showing a significant relationship between the level of remuneration and turnover intentions of secondary school teachers in Meru County. The results conclude that teachers' motivation in secondary schools in Meru County is low. Schools are also staffed with teachers with poor morale and low levels of commitment to their jobs due to inadequate and low remuneration. This has led to high turnover intentions. The study recommends that the Teachers Service Commission should consider issues of remuneration especially enhancing the current allowances and introducing new ones in motivating and reducing turnover intentions. Hence, this will lead to increased retention in teaching service.
\end{abstract}

Keywords: Level of remuneration, Turnover intentions, Motivation 


\subsection{Background Information}

Turnover in an organization is either voluntary or involuntary. Voluntary turnover is initiated by an employee willingly, while involuntary turnover is initiated by the employer to the employee when the employee violates workplace policies, poor performance, or business slowdown (Dressler \& Varkey, 2011). According to Allensworth, Ponscia, and Mazezo (2009), teacher turnover compromises of instruction by diverting resources from the classroom. This is a position also taken by Grisson (2011) who noted that it widens the gaps between the low income and wealthier schools and also reduces school's capacity to develop programmes and implement curricula. Further, schools with high turnover are forced to employ a large number of inexperienced teachers who are likely to be ineffective than those with teaching experience. This therefore disrupts instructional continuity in schools leading to disruption of learning. Therefore, enhancing retention of experienced teachers by reducing turnover intention as an antecedent of actual turnover would be an effective and obvious strategy to improve teaching effectiveness in schools (TNTP, 2012).

Boe, Cook, and Sunderland (2008) identified two types of teacher turnover: transfer which leads a teacher to relocate to another school, and attrition, which involves leaving teaching job altogether. According to Ingersoll and Merill (2012), either of them matters little to a school since the systematic impact is the same. For example, there would be high costs due to pedagogical disturbance because of the replacement of an already effective teacher with an inexperienced teacher. Teacher turnover intentions just like actual turnover manifests itself in two ways; first, a teacher intention to change the employer within the same profession or transfer from one school to another and second, a teacher intention to change the profession altogether (Currie \& Car Hill, 2012).

According to Krishnan and Singh (2010), turnover intention among teachers' results in low motivation in their work thus impending school goals. This is because employees (teachers) intending to move to perceived favorable work or areas show low excitement with their current work activities (Quick \& Nelson, 2011). Apart from high cases of absenteeism, workers intending to move to another job or to transfer to another work place are usually in conflict with the management, leading to disciplinary action (Jong \& Gutteling, 2006). Tarmizi (2008) assert that turnover intention in an organization erodes the commitment level of other employees in the same organization. Hence, organizations should take strategic steps to reduce turnover intentions of their employees. 


\subsection{Objective}

The objective of this study was to examine the relationship between the levels of remuneration(whether low or high) and turnover intention of public secondary school teachers in Meru County.

\subsection{Null Hypothesis}

The level of teachers' remuneration (whether high or low) is not significantly related to turnover intention of secondary school teachers in Meru County.

\subsection{Significance}

The researcher is optimistic that the study findings will inform the Teachers Service Commission and administrators of educational institutions on the need to reduce teacher turnover intention. This can be achieved through increasing teacher motivation and organizational commitment by addressing issues concerning teachers' remuneration.

\subsection{Literature Review}

Literature available (Bhatti, 2011; Kinyili, Karanja \& Namsonge, 2015; Ngethe, 2013; Tylor, 2009) indicate that competitive and fair remunerations motivate employees' retention in an organization as it is a good indication that employers value them. It is also a way in which employees measure if the time and efforts they put in work are worth leading to more attachment in the organization. Therefore, workers who are dissatisfied with low remuneration exhibit low commitment to their jobs and their organizations leading to intention to leave (Bergiel, Nguyen, Clenney, \& Taylor, 2009; Ngethe, 2013; Shoaib, 2009). Hence, higher compensation results to more committed employees as they feel they would lose much if they leave (Hotton \& Oneill, 2004; Gupta, 2008).

In addition, when compensation is lower than that of market rate, employees' retention is compromised as remuneration needs of such employees is not met (Katachathu, 2010; Guma, 2012). A study by Ramlall (2003) which sought to identify factors responsible for turnover intention among employees observed a number of reasons why they (employees) make a decision to leave an organization. The study found out that among other factors leading to turnover intention, remuneration was the most important for an employee's decision to either stay or leave an organization.

Goldhaber, Gross, and Player (2007) asserted that many employees make an assessment of the net monetary and non-monetary benefits from different occupations. Definitely, they go for a job that gives them the highest monetary gains of which teaching could be their last option. This position was also taken by Mumanyire (2005), who posit that the most important motivator 
to the teacher is monetary gains which could be in form of salaries, allowances, duty rewards among other rewards.

According to Akarete (2011), productivity among workers (teachers) is affected by several factors. One of the most important is employers' failure to compensate them (teachers) adequately for their hard work. Lotta (2012) concurred by alluding that when an employee (teacher) is motivated by being remunerated well, he/she becomes more productive, more efficient as well as more willing to work towards attainment of organizational (school) goals. Also, Rizwan and Ali (2010) alluded that a highly motivated employee (teacher) who is remunerated well serves to help the school to have a competitive advantage. This is because performance of employee (teacher) is cascaded to that of the organization (school) as well.

Muguongo Muguna, and Murithi (2015) in a study on the effects of compensation on job satisfaction among secondary school teachers in Mara Sub-County of Tharaka Nithi County showed that poor compensation is a major cause of teachers dissatisfaction. The reason is because they (teachers) perceive inequality in the services they render and what they receive in return. Christina and Anthony (2014) also found a significant and negative correlation between compensation and turnover intention $(\mathrm{r}=-0.682, \mathrm{P}=0.002)$.

Furthermore, Okumbe (2011) argues that an effective remuneration system should be one that enables the following; first, it should be able to attract a crème of potential employees in the market; second, it should be able to retain such employees that were hired; and thirdly, it should be one that is able to offer maximum motivation to such employees. Armstrong (2009) did a study on attractiveness of the teaching profession in South Africa by comparing remuneration of teaching staff with that of their counterparts in non-teaching profession. The results showed that the teaching profession is significantly unattractive in the job market in South Africa. This could be attributed to low salaries, poor working conditions as well as heavy workload. Michael (2008) found that a competitive salary package is the most important motivational variable that contributes to retaining employees in an organization. Wambugu (2015) also found that, generally, teachers in Nairobi County were dissatisfied with the amount of salary they earned from their employer, Teachers Service Commission, since it was insufficient.

Ayuninnisa and Saptoto (2015), in their study, concluded that pay level has a higher correlation to an employees' intention to leave than other dimensions. This means that the level of pay an employee receives is important for an employee who thinks of quitting his/her current job and seek another in a different organization. The study results indicated a moderate and negative correlation between pay level and turnover intention. This signifies that when employees are happy with their pay level, they are satisfied. Hence, they have less intention to search for another job elsewhere. This finding was in 
agreement with the findings of another study by Akhtar, Anwan, Anwar, Saeed, Ali, and Qurban (2016) who found that turnover intention is negatively and significantly associated with the level of salary. This implies that a decrease in salary of an employee directly leads to an increase in turnover intention. Thus, the reverse is true.

Mendis (2017) in a study on the impact of rewards system on employee turnover intention in a logistics industry in Sri-lanka also found a significant negative relationship between the level of remuneration $(r=-0.905, p=0.001)$ and turnover intention. According to Mutune and Orodho (2014) in the study titled "Teachers turnover; What are the explanatory variables in public secondary schools in Mbere Sub-county", teaching is still the poorest paying job in Kenya today. Further, they asserted that quality teachers cannot be retained in such poor conditions. Moreover, teachers feel they can be paid better either in private sector or in other ministries other than the Teachers Service Commission (Orodho et al., 2013).

Some scholars and researchers however noted that despite remuneration especially in form of salary and allowances being a very important extrinsic reward to employees and provides most extrinsic needs, it does not provide the much needed intrinsic motivation to employees. For example, scholars (Armstrong, 2010; Beardwell \& Claydon, 2007; Ngethe, 2013) noted that terms and conditions of service play an important role in employee motivation and organizational commitment but asserts that other factors are also important.

However, although remuneration is not the only important motivational incentive for employee retention, its importance cannot be under-rated especially when it comes to the teaching fraternity as shown by various studies. For example, Herbert and Ramsey (2003) in Ruto (2014) in their study indicated that among those dissatisfied with teaching in Texas USA, 61 percent cited poor salaries, 32 percent mentioned poor administration support, and 24 percent cited student discipline problems.

\subsection{Theoretical Framework}

The study was guided by equity theory of motivation by Stacy Adams as cited by Miringu (2017), Orina (2014), and Spector (2008). The theory postulates that workers (teachers) keep comparing the inputs (education, efforts, time, commitment and experience) they put into the job and the outcome (remuneration, recognition, promotion and other working conditions) they get from a job with their peers in other professions and similar organizations. If they perceive or detect unfair treatment, then turnover intention arises (Armstrong, 2010; Kinyili et al., 2014; Miringu, 2017; Orina, 2014; Robbins \& Decenso, 2012; Spector, 2008). 
The theory explains that, in their comparison, if workers perceive inequity, they strive or put effort to bring equity (input/ outcome ratio balance) through reducing their inputs into the work (by working less hours, frequent absenteeism, underperforming, paying leap service, disobedience to their superiors and even refusing to take any extra task). This can also be done through increasing output by asking for more salary or compensation. Moreover, if such efforts fail, such workers may raise a complaint to their superiors, look for an alternative job, leave the organization for another or may even opt to resign their jobs altogether (Giacometti, 2005; Miringu, 2017; Robbins \& Decenso, 2012). This theory is therefore applicable in understanding turnover intention of teachers in public secondary schools in Kenya. Subsequently, teachers keep comparing their remuneration especially allowances, promotional opportunities, working conditions and other aspects of the teaching job with their equivalents in similar organizations in public service. This explains why teachers in Kenya have severally gone on national wide strike led by their unions (KUPPET and KNUT) demanding for better pay and better working conditions since they compare what they earn with what other public servants of similar caliber earn.

The major strength of this theory is its emphasis on recognition of individual inputs like education, experience, and efforts for equity to be realized. However, the major weakness of this theory is its subjectivity in comparison process. For example, it is in the nature of human beings to try to distort facts about inputs, mostly efforts, hence being subjective when comparing (Beardwell \& Claydon, 2007). Further, maintaining equity within the same organization or even between different organizations is a herculean task due to existence of structural, logistical, and organizational differences of employees working in the same organization or different organizations (Spector, 2008).

\subsection{Methodology}

This study used a descriptive research design specifically cross-sectional survey design. It also employed both quantitative and qualitative approaches in data collection and analysis as proposed by Mugenda (2008), who stated that descriptive researches are conducted in communities to establish a wide range of issues such as health, nutrition, education, crime among others. According to Babbie (2010), a cross sectional survey method is the most commonly used research method in social research. This is because the results of such a survey method are easily extrapolated to the entire population since it involves observations of a sample or cross-section of a population or phenomena that are made at one point in time. All secondary school teachers including all the principals in public secondary schools in Meru County were 
involved in the study. Meru County has a total of 367 public secondary schools and a total of 2,582 teachers employed by the Teachers Service Commission.

Consequently, stratified proportionate sampling procedure was used to select twenty percent of the schools used for the study in each sub-county. This is based on the number of schools in each sub-county as proposed by Gay, Mills, and Airasian (2009). Mugenda and Mugenda (2003) also contended that social researchers recommend that 10 percent to 30 percent of the accessible population is enough and at least 30 cases are required per group for statistical data analysis. Based on this, 73 secondary schools (55 day and 18 boarding) which are 20 percent of the total number of schools were used in the study. With a total population of 2,582 teachers in Meru County, the sample size was determined through the same method. Therefore, 516 teachers were selected for this study. 15 secondary school principals were also sampled to participate in the study.

Questionnaires were used to collect quantitative data from teachers, while interview schedules were used to collect qualitative data from selected principals. A closed ended questionnaire in form of 5-Likert scale based on a five point rating ranging from strongly agree to strongly disagree were administered to teachers who participated in the study. Face to face interviews were conducted with 15 secondary school principals to gather more information on the study variables, and also to clarify various issues in relation to turnover intention affecting teachers in Meru County. Principals were interviewed because they are the custodians of teachers' records as well as their supervisors. Questions included in the interview schedules were aligned to the research objectives which enabled the researcher to get the right information.

Instrument content validity was improved by expert judgment. The researcher issued copies of questionnaires to his two supervisors who went through them and gave the necessary advice on areas of improvement. Hence, this made the instrument more valid. Content validity was also ensured through a thorough review of related literature to identify the items required to measure the concepts or variables such as the level of remuneration among others. A pilot study was done through administering questionnaires to 51 respondents who were not involved in the final study. This was 10 percent of the sampled population of 516 teachers for the actual study as suggested by Connelly (2008) that a pilot sample should be ten percent of the sample projected for the larger parent study. During the piloting, respondents were asked to evaluate the questions for relevance, comprehension, meaning, and clarity. This will enable the researcher to ascertain both the validity and the reliability of the research instruments. Reliability (internal consistency) of the questionnaires was then determined using Cronbach's alpha reliability coefficient method through the help of SPPS version 21. The Cronbach's 
Alpha value $(\alpha)$ obtained for the variable was 0.862 which was deemed to be very reliable for the study.

Accordingly, descriptive statistics such as the mean, standard deviation, and percentages were estimated for all the variables of study. The information was also presented in form of frequency tables and percentages. Statistical packages for Social Sciences (SPSS) version 21.0 was used to assist in data analysis. Inferential statistics were then computed to test the stated hypothesis of the study. Chi-square goodness of fit and Pearson Product-Moment Correlation Coefficient (r) were used to test hypotheses at 95 percent level of confidence and 5 percent level of precision.

\subsection{Results and Discussions}

\subsection{Response Rate}

A total of 503 out of the expected sample size of 516 staff in the teaching profession in Meru County responded to the questionnaires. This represented a highly significant response rate of 97.48 percent. According to Mugenda and Mugenda (2003), a 50 percent response rate is adequate, a 60 percent response rate is good, and a 70 percent and above response rate is very good. At the same time, 15 principals of secondary schools were sampled for face to face interview out of 73 public secondary schools sampled for this study.

\subsection{Relationship Between the Level of Remuneration and Turnover Intentions of Secondary School Teachers in Meru County}

The objective of this study was to examine the relationship between the level of remuneration (whether low or high) and turnover intention of public secondary school teachers in Meru County. Nine items were used to study this variable which was assessed on a 5 point Likert scale ranging from 1-strongly agree to 5- strongly disagree. The detailed descriptive results for the objective are shown in Table 1.

Table 1. Descriptive statistics for the Level of Remuneration and teacher turnover intentions

\begin{tabular}{|c|c|c|c|c|c|c|c|c|}
\hline & Mean & SDev & $\mathrm{N}$ & $\begin{array}{l}\text { SA } \\
(\%)\end{array}$ & $\begin{array}{l}\text { A } \\
(\%)\end{array}$ & $\begin{array}{l}\mathrm{ND} \\
(\%)\end{array}$ & $\begin{array}{l}\mathrm{D} \\
(\%)\end{array}$ & $\begin{array}{l}\text { SD } \\
(\%)\end{array}$ \\
\hline $\begin{array}{l}\text { The salary I earn is adequate to meet my needs } \\
\text { which makes me to stay }\end{array}$ & 1.92 & .946 & 502 & 1.2 & 7.0 & 12.9 & 40.4 & 38.4 \\
\hline $\begin{array}{l}\text { My employer TSC offers attractive house } \\
\text { allowance which encourages me to remain }\end{array}$ & 1.85 & .881 & 502 & 1.0 & 5.4 & 10.3 & 44.1 & 39.2 \\
\hline $\begin{array}{l}\text { My employer TSC offers attractive travel } \\
\text { allowance which encourages me to stay }\end{array}$ & 1.72 & .837 & 502 & 0.6 & 4.2 & 8.7 & 39.4 & 47.1 \\
\hline $\begin{array}{l}\text { My employer TSC offers attractive leave } \\
\text { allowance which motivates me to stay }\end{array}$ & 1.68 & .859 & 502 & 0.8 & 3.8 & 9.7 & 33.4 & 52.3 \\
\hline
\end{tabular}




\begin{tabular}{|c|c|c|c|c|c|c|c|c|}
\hline $\begin{array}{l}\text { My employer TSC offers attractive medical } \\
\text { allowance which encourages me to stay }\end{array}$ & 1.56 & .826 & 502 & 1.0 & 3.4 & 5.6 & 30.2 & 59.8 \\
\hline $\begin{array}{l}\text { The salary I earn is higher than what other } \\
\text { professionals of the same caliber earn which } \\
\text { motivates me to remain in teaching }\end{array}$ & 1.48 & .803 & 502 & 1.8 & 1.6 & 4.2 & 27.6 & 64.8 \\
\hline $\begin{array}{l}\text { The remuneration in the TSC is competitive } \\
\text { which encourages me to stay in teaching }\end{array}$ & 1.55 & .753 & 502 & 1.4 & 1.4 & 3.4 & 38.6 & 55.3 \\
\hline $\begin{array}{l}\text { Salary raises are regular which motivates me to } \\
\text { stay }\end{array}$ & 1.57 & .773 & 502 & 0.6 & 2.6 & 6.2 & 34.0 & 56.7 \\
\hline $\begin{array}{l}\text { Financial incentives such as overtime bonuses, } \\
\text { extra-curricular activities, remedial teaching etc. } \\
\text { given by my employer encourages me to stay }\end{array}$ & 1.54 & .863 & 502 & 1.8 & 3.2 & 4.4 & 28.2 & 62.4 \\
\hline
\end{tabular}

According to detailed descriptive results in Table 1, majority of the respondents strongly disagreed with statements of the study variable items with a very low mean of less than 2 on a scale of 1 to 5 . This implies that secondary school teachers in Meru County are highly dissatisfied with all the items of the variable. Thus, this has led to high turnover intentions which are occasioned by dissatisfaction with low levels of remuneration. For example, the mean of 1.48 for the item "The salary I earn is higher than what other professionals earn which motivates me to remain in teaching" was very low (standard deviation of 0.803 ). The mean of 1.92 for the item "The salary I earn is adequate to meet my needs which makes me to stay" is also low (standard deviation of 0.96).The results therefore show that on a scale of 1-5, the level of dissatisfaction with the level of remuneration in the teaching fraternity is very low leading to high turnover intention.

It is significantly important to note the high level of dissatisfaction with the amount of allowances teachers receive from their employer, Teachers Service Commission. For example, dissatisfaction with house allowance had a mean of 1.85 , medical allowance with a mean of 1.56 , travel allowance with a mean of 1.72, and leave allowance had a mean of 1.68. These findings are in agreement with a study by Wambugu (2015) who found that secondary school teachers in Nairobi County have low satisfaction with the low remuneration they earn with a mean of 1.796 and standard deviation of 0.654 .

These results are also in agreement with the qualitative results obtained from the interviews from principals. All Principals interviewed indicated that the issue of salaries is a big motivational issue for teachers in Kenya. Also, most secondary school teachers complain about their salaries being low as compared to what other professionals of the same caliber get, and in particular aspects, like monthly salary, periodic salary adjustments, and allowances. Furthermore, teachers' pay is low relative to other professionals especially for those in the public sector such as nurses who are considerably paid better 
salaries and allowances than graduate teachers. This is despite the fact that teachers have better academic qualifications. This assertion is in agreement with Jonathan, Thibeli, and Darroux (2013) who contends that improving work conditions and staff welfare though streamlining salary structures and aligning teachers' salary with those of other professionals' leads to improvements in job satisfaction resulting to reduced turnover intentions.

Salami (2008) agrees in his study findings that professionals who are well remunerated benefit their organizations throughout their career span. The reason is that such employees are satisfied and motivated to work with no intention to leave. These results also agree with the results of a study by Koech, Tikoko, and Chemwei (2014) on institutional factors influencing teachers' turnover in Baringo County, Kenya. Waititu (2010) also conducted a study on factors influencing teacher turnover in Limuru District. The two studies were in conclusion that among other factors influencing teacher turnover, salary was the most significant. Waititu (2010), in particular, reported that 96 percent of the teachers were not satisfied with their salaries as they were paid less than what other professionals of equivalent qualifications earn. Hence, they would not mind leaving teaching if an opportunity for a better job arises. Principals interviewed reported that salary issues for teachers are matters which the Teachers Service Commission is required to look into so as to improve teachers' motivation and reduce turnover intentions within the teaching fraternity. One of the principals expressed the following sentiments about the level of remuneration of public secondary school teachers;

Teachers are paid lower salaries compared to other professionals. The allowances given are very low and limited (few) compared to other professionals such as doctors, nurses, lawyers, and engineers. Yet the work teachers do is too much including but not limited to controlling students in and out of school, managing students' behavior, marking students work, and classroom teaching. There is a lot of government control hence no autonomy and to make matters worse, there is a lot of pressure from stakeholders to perform. This makes many teachers have a lot of stress, dissatisfaction, and a lot of demotivation. This actually makes many teachers very eager to leave teaching any time an opportunity for an alternative job arises.

The same Principal reported that most secondary school teachers are not committed to their primary role of teaching. Most of them complement their low salaries by engaging in non-teaching activities such as farming, businesses, and doing extra tuition. However, those with higher qualifications such as masters degrees engage in moonlighting in several Universities and Colleges to get an extra coin. This leads to a lot of absenteeism in schools and resulting to poor performance of students. This finding is in agreement with Nguni (2005) who reported a majority of teachers complaining of poor salaries which explains why most teachers embark on second jobs to the detriment of schools and the students. 


\subsection{Inferential Statistics}

The second part of data analysis involved generation of inferential statistics through testing of research hypothesis. The null hypothesis Ho1: The level of remuneration (whether low or high) is not significantly related to turnover intentions of secondary school teachers in Meru County. This was tested using Pearson Product-Moment Correlation Coefficient and Chi-square goodness of fit at 95 percent level of significance and 5 percent level of precision. The null hypothesis suggests that the independent variable, level of remuneration, and the dependent variable, turnover intention, are independent of one another. The researcher was interested in finding out whether there was any relationship between the level of remuneration and turnover intentions of secondary school teachers in Meru County. Pearson Product-Moment Correlation Coefficient ( $r$ ) was used to test the strength and direction of relationship between the independent variable (level of remuneration) and the dependent variable (turnover intention). However, Chi-square was used to determine the significant level of relationship between the two variables, the independent and the dependent variable.

\subsubsection{Results of Pearsons Correlation Analysis}

Table 2. Pearson Correlation between the level of remuneration and teacher turnover intention

\begin{tabular}{lcc}
\hline & LR & ITL \\
\hline LR - Pearson Correlation & 1 & -.387 \\
Fig (2-tailed) & .000 & .000 \\
$\mathrm{~N}$ & 502 & 502 \\
$\mathrm{ITL} \quad$ Pearson Correlation & -.387 & 1 \\
Fig (2-tailed) & .000 & .000 \\
$\mathrm{~N}$ & 502 & 502
\end{tabular}

The pearson's correlation results as shown in Table 2 indicate a significant and negative linear correlation $(r=-0.387, p<0.001)$ between the level of remuneration and turnover intentions of public secondary school teachers in Meru County. This implies that the level of remuneration and teacher turnover intentions among public secondary school teachers in Meru County have a significant negative linear correlation. This means that improvement in the level of remuneration reduces turnover intentions and the reverse is true. These results agree with the literature reviewed that attractive remunerations reduce turnover intentions since it leads to fulfillment of the financial and materials needs. At the same time, it also raises employee status. For example, the findings by Khan and Qadir (2016) identified a significance 
inverse (negative) relationship $(\mathrm{r}=-0.867, \mathrm{p}<0.01)$ between remuneration and teacher turnover intentions in Bahria schools and colleges at Karachi, Pakistani.

These findings are also in tandem with Zerha et al. (2013) who concluded that high pay is negatively related to turnover intentions $(r=-0.31$, $\mathrm{p}=0.001$ ). This means that when employees' are paid fair and competitive salaries, having intentions to leave the organization reduces. Also, at the same time, this increases employee loyalty to the job and the organization. This finding is also in agreement with Ramlall (2003), Katachathu (2010), and Guma, (2012) who indicated that when employee's compensation is lower than the market rate, retention rate will be low because the remuneration needs of such employees are not met.

\subsubsection{Test of Hypothesis-Chi-Square Goodness of Fit}

The results of test of hypothesis by Chi-square for the level of remuneration as shown in Table 3 concur with the results of Pearson ProductMoment Correlation. This shows that the Pearson Chi-Square of 12.221 with 4 degrees of freedom and associated $p$-value (Asymptotic significance) was 0.000 which is highly significant at $p<0.005$. This indicated an evidence against the stated null hypothesis that the level of remuneration (whether low or high) is not significantly related to turnover intentions of secondary school teachers in Meru County leading to its rejection.

The results therefore concluded that the level of remuneration (whether low or high) is significantly related to turnover intentions of public secondary school teachers in Meru County. This implies that if the level of remuneration is increased, teachers will be satisfied and motivated leading to reduction of turnover intentions (Bennel, 2007). These results are in agreement with Muguongo, Muguna, and Muriithi (2015) and Kwenin (2013) who found a significant relationship between salaries and job satisfaction. However, these findings did not agree with the findings of Odunlade (2012) who found no relationship between the level of remuneration (allowances) and job satisfaction. Mba and Ikemefuna (2012) also stated that the higher the satisfaction with pay, the lower the employee turnover intentions.

Table 3.Chi-Square test between the level of remuneration and turnover intentions

\begin{tabular}{llll}
\hline & & & $\begin{array}{l}\text { Asymptotic } \\
\text { Significance } \\
\text { sided) }\end{array}$ \\
\hline Pearson Chi-Square & Value & df & .016 \\
Likelihood Ratio & $12.221^{\mathrm{a}}$ & 4 & .072 \\
Linear-by-Linear Association & 8.608 & 4 & .004 \\
N of Valid Cases & 8.384 & 1 & \\
\hline 4 cells $(44.4 \%)$ have expected count less than 5. The minimum expected count is .82
\end{tabular}




\subsection{Summary and Conclusion}

The objective of the study was to examine the relationship between the level of remuneration and turnover intentions of public secondary school teachers in Meru County.

The quantitative descriptive results from the questionnaires showed that all items in this variable were significantly related to turnover intentions of secondary school teachers in Meru County. These results were corroborated by qualitative results from interviews of secondary school principals. They concurred that most teachers in Meru County are not happy with their salaries, and at the slightest chance would leave teaching if they got a better paying job. The results also indicated that majority of teachers in Meru County were not satisfied with low pay and allowances offered to them by their employer, Teachers Service Commission.

In addition, the inferential statistics in this study (Pearson ProductMoment correlation results) also show that the level of remuneration and teacher turnover intentions among public secondary school teachers in Meru County have a significant negative or inverse linear correlation $(r=-0.387, \mathrm{P}<$ 0.001). This means that an increase in the level of remuneration of secondary school teachers reduces turnover intentions and the reverse is true. The Pearson Chi-Square test hypothesis (12.221 with 4 degrees of freedom, $\mathrm{p}=0.000$ ) also corroborates the correlation results by concluding that there is significant association between the level of teacher remuneration and turnover intentions of secondary school teachers in Meru County. This shows that improvement in the level of remuneration among secondary school teachers in Meru County reduces the turnover intentions and vice versa.

The results concluded that the pay and allowances together with other incentives given to teachers were inadequate and not comparable to what other professionals earn. Hence, this has created a major source of dissatisfaction and turnover intentions. The results therefore concurred with literature reviewed that indeed inadequate teacher remuneration leads to high turnover intention among secondary school teachers.

6.0 Recommendations

It is recommended that the Teachers Service Commission take measures to improve the levels of remuneration by undertaking reviews regularly and effectively. This will help to reduce the teacher intention to leave teaching. The level of remuneration should also be managed with a view to ensure retention and focus on the job. This will play a great role in ensuring focus, quality of teaching and learning as well as attract good quality staff from leaving the teaching profession.

Although rewards in form of salaries are being addressed by the Teachers Service Commission, the study recommends the enhancement of existing allowances offered to teachers as well as adding new allowances such 
as overtime allowance, extraneous allowances among others. This is due to the fact that the work that teachers do is enormous including but not limited to working at night, weekends as well as marking students' scripts and controlling discipline. Sometimes this may lead to serious confrontations resulting to disastrous outcomes mainly on the teacher.

\section{References:}

1. Akerele, P.M. (2011). Human Resource Management (5 $5^{\text {th }}$ Ed). New York, McGraw-Hill.

2. Akhtar, N., Awan, A.W.A., Anwar, M.A., Saeed, S., Ali, S., \& Qurban, M. (2016). Impact of Job Satisfaction and Remuneration on Turnover Intention: A Survey of Private Schools of Okara, Pakistan. International Review of Management and Business Research, 5 (2), 653-675.

3. Allensworth, E., Poniscia, K S.,\& Mazzeo, C.(2009).The Schools Teachers Leave: Teacher mobility in Chicago Public schools. Chicago: Consortium on Chicago school Research-University Chicago.

4. Armstrong, M.A. (2010).Handbook of human management practices $\left(13^{\text {th }}\right.$ Ed.). London. Kogan page

5. Armstrong, M.A. (2009).Armstrong's handbook of performance management. An evidence based guide to delivering high performance. London, Kogan page.

6. Ayuninnisa, R.N., \& Saptoto, R. (2015).The effects of pay satisfaction and effective commitment on turnover intentions. International Journal of Resource Studies in Psychology, 4(2)57-70.

7. Babbie, E.R. (2010). The Practice of Social Research $\left(12^{\text {th }} \mathrm{ed}\right)$. Wadsworth, London: Centage Learning.

8. Beardwell, J. \& claydon, T. (2007). Human resource management. A contemporary Approach. London. Prentice Hall.

9. Bergiel, B.E., Nguyen, V.Q., Clenney, B.F., \& Taylor, G.S. (2009). Human Resource Practice $\left(11^{\text {th }}\right.$ ed) .London: Kogan page limited.

10. Bhatti, S. (2007). Human resource management. A competitive advantage. Indian journal of industrial relations. 42 (4),746-751

11. Bennel, P., \& Akyeampong, K. (2007).Teacher motivation in SubSaharan Africa and South Asia. Education papers. Retrieved fromwww.dfd.gov.uk/R4D/PDF/outputs/policystrategy,Researching.

12. Boe, E.E., Cook, L.H., \& Sunderland, R.J. (2008).Teacher turnover. Examining exit attrition, Teaching area, transfer and school migration, Journal of exceptional children, 75 (1) 7-31. 
13. Curry, E.J. \& Hill, R.A.C. (2012). What are the reasons for high turnover in nursing? A discussion, presumed causal factors and remedies. International journal of Nursing Studies, 49(9), 1180-1189

14. Dressler, G., \& Varkey, B. (2011). Human resource management .New Delhi: Pearson Education.

15. Dressler, G. (2013). Human resource management (13 ${ }^{\text {th }}$ ed). London. Pearson Education, Inc. Prentice hall.

16. Gay,L.R., Mills, G.E., \& Airasian, P. (2009). Educational research: competencies for Analysis ( $9^{\text {th }}$ ed). New Jersey: Pearson Education.

17. Giacommetti, K.S. (2005). Factors affecting job satisfaction and retention of beginning teachers. PhD dissertation, Virginia Polytechnic Institute and State University.

18. Goldhaber, D., Gross, B., \& Player (2007). Are public schools really losing their best? Assessing the career transitions of teachers and their implications for the quality of teacher workforce. CALDER working paper 12. Washington DC:The Urban Institute.

19. Grisson, J. A. (2011).Can good principals keep teachers in disadvantaged schools? Linking principal effectiveness to teacher satisfaction and turnover in hard to staff environment. Teachers College Records, 113(11)2552-2585

20. Guma, P.V. (2012). Organizational factors Impacting on Employee Retention. Masters of Business Administration Thesis. Nelson Mandela Metropolitan University.

21. Gupta, S. (2009). Human resource development, concepts and practices; Deep and Deep Publishers.

22. Holton, B.C., \& Oneill, B.S. (2004). Job embeddedness. A theoretical foundation for developing a comprehensive job retention plan: Journal of nursing administration, 34 (5), 216-227

23. Ingersoll, R.M., \&Merill, L. (2012). Seven Trends. The transformation of the teaching force. The consortitium for policy research in education.

24. Jonathan, H., Thibeli, M., \& Darroux, C. (2013). Impact of investigation of organizational commitment on intention to leave of public secondary school teachers in Tanzania. Developing country studies, 3(11), 78-91.

25. Jong, M.D., \& Gutteling, C. (2009). Relationship between organizational identity, identification and organizational objectives. An empirical study in municipalities. OH Pub.

26. Katachathu, P. (2010).Influence of Human Resource Practices on Employee Retention. Masters Thesis, University of Malaysia 
27. Khan, R.A., \& Qadir, M.I. (2016). Determinants of teacher turnover intentions in Bharia Schools and Colleges at Karachi. Journal of Business Studies, 12 (1),198-218 pharmacy, 6, 5(23) 2276-2284

28. Kinyili, J.M., Karanja, K., \& Namusonge, G.S. (2015). Role of remuneration and career advancement practices on the retention of employees in organizations. International Journal of Advanced Research in Management and Social Sciences, 4(7)254-276.

29. Koech, S.J., Tikoko, B.J., \& Chemwei, B. (2014).Institutional factors that influence teachers' turnover in public secondary schools in Baringo County, Kenya. International Journal of Education and Research, 2(3), 20-39

30. Krishman, S.K., \& Singh. (2010). Outcomes of intentions to quit of Judean Professionals. Human resource management, 49(3):28-36

31. Kwenin, D.O. (2013).Relationship between Work Environment, Career Development Opportunities and Employee Retention in Vodafone Ghana Limited. Global Journal of Human Resource Management, 1(4), 1-9

32. Kwenin,D.O., Muathe, S.,\& Nzulwa, R.(2013).Influence of Employee Rewards, Human Resource Policies and Job Satisfaction on Retention of Employees in Vodafone Ghana Limited. European Journal of Business and Management, 5(12), 13-20

33. Lotta, H.J. (2012).Training and development practices in an organization: An intervention to enhance organizational effectiveness. International journal of Engineering and Management Science, 2(4), 187-198

34. Mbah, S., \& Ikemefuna, C. (2011). Job satisfaction and employee turnover intentions in total Nigeria, PLC, Lagos. International journal of humanities and social sciences, 2 (14), 275-287

35. Mendis, M.V.S. (2017).The Impact of Reward System on Employee Turnover Intention. A study on Logistics Industry of Sri-Lanka .International Journal of Scientific and Technology Research, 6 (9) 6772.

36. Miringu, A.N.,Ngugi, P.K., Were, S.,\& Odhiambo, R.(2017).Does Career Progression Nudge Labour Mobility Intentions of Teaching Personnel in Teachers Service Commission Tartiary Institutions in Kenya? International journal of Academic Research in business and social sciences, 7(1), 141-152

37. Mohamed, J.A., Gerry, F., \& Michele, C. (2012).The relationship between quality of work life and turnover intention of primary health care nurses in Saudi ribia.BMC Health Services Research Journal, 12:314. doi:10.1186/1472-6963-12-314. 
38. Mugenda, O.M., \& Mugenda, A.G (2003). Research methods: Quantitative and Qualitative approaches .Nairobi: Acts Press.

39. Mugenda, A.G. (2008). Social Science Research, Theory and Principles .Applied Research and Training Services. Nairobi, Mosel publishers.

40. Muguongo, M.M., Muguna, A.T., \& Muriithi, D.K. (2015).Effects of Compensation on Job Satisfaction among secondary school teachers in Maara Sub-County,Tharaka Nithi County, Kenya. Journal of Human Resource Management, 3(6), 47-59

41. Mumanyire, M. (2005). Factors affecting teacher motivation in secondary schools in Mukono District. Unpublished Master of Education dissertation, Makerere University, Kampala, Uganda

42. Mutune, J.M., \& Orodho, J.A.(2014).Teachers' turnover. What are the explanatory variables in public secondary schools in Mbeere south sub-county, Embu County, Kenya? Journal of humanities and social sciences, 19, (12), 11-24.

43. Ng'ethe, J.M. (2013). Determinants of academic staff retention in public universities in Kenya. PhD thesis, Jomo Kenyatta University of Agriculture and Technology.

44. Nguni, S.C.(2005). Transformational Leadership in Tanzanian Education: A study of Effects of Transformational Leadership on Teachers' Job Satisfaction, organizational commitment and organizational citizenship behavior in Tanzania primary and secondary schools. Radbound, Nijmegen, the Netherlands.

45. Odunlade, R.O. (2012).Managing Employee Compensation and Benefits for Job satisfaction in Libraries and Information Centers in Nigeria. Available http://unllib.unl.educ/LPP/

46. Okumbe, J.A. (2011). Human Resource Management. An Educational perspective: Nairobi: Education Development and Research Bureau.

47. Orina, W.A. (2014). Assessment of factors leading to early retirement of public secondary school teachers in Kajiado county, Kenya. Masters of education thesis. The Catholic University of East Africa.

48. Orodho, A.J., Waweru, P.N., Ndichu, \& Nthiguri. (2013). Basic education in Kenya. Focus on strategies applied to cope with school based challenges inhibiting effective implementation of curriculum. International journal of education and research, 1 (11), 1-10

49. Quick, J.C. \& Nelson, D.L (2011). Principles of organizational behavior, realities and Challenges ;South eastern . Cengage learning, Singapore.

50. Ramlall, S. (2003).Organizational Application. Managing Employee Retention as a Strategy For Increasing Organizational Competitiveness. Applied H.R.M . Research, 8(2), 63-72 
51. Rizwan, Q.D., \& Ali, U. (2010).Impact of reward and recognition on job satisfaction and motivation. An empirical study from Pakistan. International Journal of Business and Management, 5(2), 159-167

52. Robbins, S.P., Decenzo, D.A., \& Verhulst, S.L. (2012). Fundamentals of Human Resource Management, (1 $11^{\text {th }}$ Ed.). Willey E- TEXT ISBN: 978-1-118-545447

53. Ruto, J.K. (2014). Factors influencing teachers' voluntary turnover in public secondary schools in Kuresoi Sub-County, Kenya. Unpublished MBA Project, Kabarak University.

54. Salami, S.O. (2008). Demographic and Psychological factors predicting organizational commitment among industrial workers. Anthropologist, 10(1), 31-38

55. Samuel, O., \& Chipunza, C. (2009). Employee retention and turnover: Using Motivational Variable as a panacea. African Journal of Business Management, 3(8), 410-415

56. Shoaib, M., Noor, A., Tirmiziz, S., \& Bashir, S. (2009). Determinants of employee Retention in telecom sector of Pakistan. Proceedings $2^{\text {nd }}$ CBRC, Lahore Pakistan, 14th Nov, 2009.

57. Spector, P.E. (2008).Industrial and Organizational Behavior $\left(5^{\text {th }}\right.$ ed.).Wiley Hoboken, NJ.

58. TNTP (2012). The irreplaceable. Understanding the real retention crisis in America's Urban Schools. Brooklyn: TNTP

59. Waititu, G.M. (2013).An analysis of factors influencing turnover of teachers in public high schools in Limuru District, Kenya .Unpublished master of education thesis, Kenyatta University.

60. Wambugu, T.W., \& Busienei, J.R. (2015).Factors leading to Job Satisfaction of public secondary school teachers in Nairobi County, Kenya. Strategic Journal of Business and Change Management, 2(122), 1988-2008.

61. Zahra, S., Irum, A., Saad, M.,\& Chishti ,A.(2013).Job satisfaction and faculty turnover intentions. A case of Pakistan University. Journal of business and management, vol. 9 issue 2. 